\title{
IMPACT INJURY DIAGNOSIS IN MANGO THROUGH STARCH DEGRADATION INDEX $^{1}$
}

\author{
FRANCISCO DE ASSIS DE SOUSA ${ }^{2}$, RAILENE HÉRICA CARLOS ROCHA ${ }^{2 *}$, INÁCIA DOS SANTOS MOREIRA ${ }^{2}$, \\ TÁDRIA CRISTIANE DE SOUSA FURTUNATO², JOSÉ FRANCIRALDO DE LIMA ${ }^{3}$
}

\begin{abstract}
This study aimed to evaluate the use of starch degradation index (SDI) in the diagnosis of areas of impact injuries in 'Tommy Atkins' mango, in different maturation stages. The experiment layout was a fully randomized factorial design ( $5 \times 2$ ), represented by five maturation stages and two handlings, with and without impact, with four replicates. SDI was determined through a subjective scale of scores indicating mango pulp darkened areas by reaction with iodine-potassium iodide solution. Subsequently, these scores were correlated with physicochemical quality variables. The results showed no influence of impact on fruit quality, in any of the studied maturation stages. Moreover, soluble solid contents increased throughout maturation stages, regardless of whether the fruits suffered impact or not. As a result, SDI is unsuitable to indicate fruit impact injury. However, there is a good correlation between SDI and pulp color, vitamin $\mathrm{C}, \mathrm{pH}$, titratable acidity, soluble solids, SS/ TA ratio and non-reducing sugars.
\end{abstract}

Keywords: Mangifera indica L.. Mechanical injury. Maturation.

\section{DIAGNOSE DE INJÚRIA POR IMPACTO EM MANGA ATRAVÉS DO INDICE DE DEGRADAÇÃO DE AMIDO}

RESUMO - O presente trabalho teve como objetivo avaliar o índice de degradação de amido (IDA) na diagnose de áreas injurias por impacto na manga 'Tommy Atkins', em diferentes estádios de maturação. Utilizou-se o delineamento inteiramente ao acaso (DIC) em esquema fatorial ( 5 x 2), representado por cinco estádios de maturação e duas condições de manuseio, com e sem impacto, com quatro repetições. $\mathrm{O}$ índice de degradação de amido foi estabelecido através de escala subjetiva de notas indicativas de proporções da área da polpa da manga escurecida em função da reação com solução de iodo-iodeto de potássio e posteriormente, estas notas foram correlacionadas com variáveis físico-químicas de qualidade. O impacto não influenciou na qualidade dos frutos, em nenhum dos estádios de maturação estudado, os sólidos solúveis aumentaram com o avanço dos estádios de maturação da manga, independentemente se os frutos sofreram impacto. O índice de degradação de amido não é adequado para ser utilizado como um indicativo de frutos com injúria por impacto. Há uma boa correlação do índice de degradação de amido com a cor da polpa, vitamina $\mathrm{C}$, pH, acidez titulável, sólidos solúveis, relação SS/AT e açúcares não redutores.

Palavras-chave: Mangifera indica L.. Injúria mecânica. Maturação.

\footnotetext{
*Corresponding author

${ }^{1}$ Received for publication in 08/07/2015; accepted in 08/19/2016.

Paper extracted from the monograph of the first author.

${ }^{2}$ Center of Agrifood Science and Technology, Universidade Federal de Campina Grande, Pombal, PB, Brazil; franciscoufcg@gmail.com, raileneherica@ccta.ufcg.edu.br, inaciamoreira@ymail.com, tadriacsf@hotmail.com.

${ }^{3}$ Biotechnology Sector, Institute Fazenda Tamanduá, Santa Teresinha, PB, Brazil; josefranciraldo@gmail.com.
} 


\section{INTRODUCTION}

Brazil stands out worldwide as one of the largest mango (Mangifera indica L.) producers and exporters. Currently, in northeast region of the country, mango is one of the most important crops due to its large volume of production and exports (PACHECO, 2015). Despite the high technological level of international market logistics, fast and practical identification methods for fruit internal quality are still required. Certain fruit physical and chemical quality parameters, such as pulp firmness, color uniformity, content of sugars, among others, are of major importance for determining harvest point, according to market requirements.

Some authors have been using starch degradation index (SDI) to measure fruit harvest point (BROOKFIELD et al., 1997; ROCHA et al., 2001), aiming to detect starch in fruit and vegetables through browning. SDI points to starch content determined on the rule of darkening of pulp areas brushed with iodine-potassium iodide based solutions (BROOKFIELD et al., 1997). Therefore, using a color scale to analyze the area on fruit pulp dyed with the solution may help characterizing its chemical quality.

In mango, there is a strong correlation of SDI and variations in starch, reducing sugars, non-reducing sugars, soluble solids, skin color, pulp color, pulp firmness, $\mathrm{pH}$ and titratable acidity. Perhaps, it may be an efficacious alternative to estimate fruit quality and maturation in the field (ROCHA et al., 2001).

Therefore, this study aimed to evaluate the quality of 'Tommy Atkins' mango with and without impact injuries, at different maturation stages, using an iodine-potassium iodide based solution as fruit maturation and quality index.

\section{MATERIAL AND METHODS}

The fruits of 'Tommy Atkins' mango used in this study were provided by the Agency for Agriculture and Livestock Research of Paraíba State (EMEPA). They were gathered at an experimental station, in the city of Aparecida-PB, Brazil. It is in an irrigated district of Várzeas de Sousa - PB (PIVAS). Harvest was carried out in the morning using pruning scissors, cutting the peduncle at $5 \mathrm{~cm}$ above calyx to prevent latex from flowing onto fruit skin. Afterwards, these samples were placed into plastic boxes, covered with newspaper and transported to the Laboratory of Agricultural Products (LTPA) of the Federal University of Campina Grande (UFCG), Campus in Pombal-PB, Brazil.

At the laboratory, peduncles were cut to $0.5 \mathrm{~cm}$; fruits were washed in tap water, immersed into a chlorinated water $(150 \mathrm{ppm} / \mathrm{L})$ for 15 minutes and naturally dried at room temperature.

The fruits were previously characterized for pulp and skin color according to Protrade (1992) and the pulp was classified as follows: 1 - Green fruit; 2 - Fruit with traces of yellow; 3 - More green than yellow; 4 - More yellow than green; and 5 - Traces of green. For skin color, the same scale was used, varying from green to red.

A completely randomized design (CRD) was used, in a $5 \times 2$ factorial scheme (maturation stages $\mathrm{x}$ handling conditions), with four replicates and two fruits per replicate, totaling 80 fruits. For the handling conditions, fruits with and without mechanical injuries were considered. Impact injury was simulated at laboratory by reproducing fruit drop from a tree whilst handing orchard harvest. To do so, fruits were dropped from $2.0 \mathrm{~m}$ onto a container filled with sand. Each fruit was bumped twice, one bump per side on the equatorial region.

Subsequently, the fruits remained on a bench, under environment conditions $\left(28^{\circ} \mathrm{C} \pm 2\right.$ and $66 \% \pm 5 \mathrm{RH}$ ), being analyzed on the seventh day of storage. The following characteristics were evaluated: 1) Fresh mass loss (FML): being the relationship between each fruit weight on the harvest day and after seven days of storage. 2) Electrolyte leakage: according to Serek et al. (1995), with results expressed as the ratio between the first and second measurement, multiplied by 100. 3) Vitamin C: determined according to the method proposed by Strohecker and Henning (1967), in duplicate. Initially, 1-g pulp was diluted in $50 \mathrm{~mL}$ oxalic acid; then, it was titrated with Tillman's solution, expressing results in $\mathrm{mg} 100 \mathrm{~g}^{-1}$ ascorbic acid. 4) Hydrogen potential $(\mathrm{pH})$ : measured directly in pulp, using a digital potentiometer $\left(\right.$ Tecnopon $^{\circledR}$, Model mPA - 210P/Version 7.1) with glass-membrane electrode (AOAC, 2005). 5) Soluble solids (SS): determined directly in homogenized pulp, through digital refractometer reading (Model PR - 100, Palette, Atago Co., LTD., Japan) with automatic temperature compensation, and expressed in percentage (AOAC, 2005). 6) SS/ TA ratio: being the quotient between both characteristics. 7) Titratable acidity (TA): determined in duplicate using a 1-g aliquot of pulp mixed with distilled water, until a volume of $50 \mathrm{~mL}$, adding two drops of $1 \%$ alcoholic phenolphthalein indicator. Then, the sample was titrated with $0.1 \mathrm{~N} \mathrm{NaOH}$ solution, previously standardized, expressing results in percentage (\%) of citric acid (AOAC, 2005). 8) Reducing and non-reducing sugars: determined by the Fehling method, following standards of the Adolfo Lutz Institute (IAL, 2008). 9) Total sugars: being the sum of reducing and non-reducing sugars, and expressed in percentage (IAL, 2008). 10) Skin color and pulp color: ascertained by means of a color scale varying from 1 to 5 (PROTRADE, 1992), from green to yellow for pulp and from green to red for 
skin. 11) Starch degradation index (SDI): fruits were longitudinally cut into halves. One part had pulp brushed with iodine-potassium iodide aqueous solution - $2.0 \mathrm{mg} \mathrm{I}_{2}: 20.0 \mathrm{mg} \mathrm{KI}: 1.0 \mathrm{ml} \mathrm{H} \mathrm{H}_{2} \mathrm{O}$ (FAN et al., 1995). Then, a subjective scale modified from Brookfield et al. (1997) estimated SDI, in which: $0=$ dark tissue, i.e. fully dyed; 1 = brightening below $10 \%$ in the middle; 2 = brightening between $10 \%$ and $20 \%$ in the middle; $3=$ brightening between $20 \%$ and $30 \% ; 4=$ brightening between $30 \%$ and $40 \%$; $5=$ brightening between $40 \%$ and $50 \%$; and $6=$ brightening above $50 \%$. Scores were given after five-minute solution application, by three evaluators, considering the mean values.

Data underwent variance analysis and means were tested by the Tukey's test at 0.05 probability. Regardless of the significance, they were all subjected to a follow-up analysis. Also, correlation analysis was performed between SDI and the analyzed quality features, using the software
SISVAR (FERREIRA, 2011).

\section{RESULTS AND DISCUSSION}

Concerning FML, there were significant differences among maturation stages for fruits without impact injury. Stage 1 fruits showed higher FML $(7.54 \%)$, while fruits in stage 5 had the lowest value $(5.43 \%)$. However, no differences were found among maturation stages for fruits with impact injury. Therefore, maturation stages had no influence from impacts (Table 1). Nonetheless, Durigan, Mattiuz and Durigan (2005) observed stronger FML in 'Tahiti'lime subjected to different mechanical injuries than uninjured fruits throughout storage. It is noteworthy remembering that mango, as most climacteric fruits, loses mass during maturation, which may be influenced by storage conditions (MANICA et al., 2001).

Table 1. Fresh mass loss (FML, \%), electrolyte leakage (EL) in 'Tommy Atkins' mango at different maturation stages, with and without impact injury, after seven days of storage $\left(28^{\circ} \mathrm{C} \pm 2\right.$ and $\left.66 \% \pm 5 \mathrm{RH}\right)$.

\begin{tabular}{|c|c|c|c|c|}
\hline $\begin{array}{l}\text { Maturation } \\
\text { stages }\end{array}$ & $\begin{array}{l}\text { FML } \\
\text { Without Impact }\end{array}$ & With impact & $\begin{array}{l}\text { Electrolyte leakage } \\
\text { Without Impact }\end{array}$ & With Impact \\
\hline 1 & $7.54 \mathrm{~b} \mathrm{~A}$ & 7.80 a $\mathrm{A}$ & 46.47 a A & 51.41 a A \\
\hline 2 & $6.99 \mathrm{ab} \mathrm{A}$ & 6.97 a A & 66.12 a A & 55.93 a A \\
\hline 3 & $6.24 \mathrm{ab} A$ & 6.22 a A & 58.62 a A & 54.91 a A \\
\hline 4 & $5.86 \mathrm{ab} \mathrm{A}$ & 6.95 a A & 59.33 a A & 59.30 a A \\
\hline 5 & $5.43 \mathrm{aA}$ & $6.71 \mathrm{a} \mathrm{A}$ & $61.20 \mathrm{a} \mathrm{A}$ & 51.69 a A \\
\hline $\mathrm{CV} \%$ & 12.70 & & 19.46 & \\
\hline Overall mean & 6.41 & 6.93 & 58.34 & 54.64 \\
\hline
\end{tabular}

*Means followed by the same letter, lowercase in column and uppercase in row, do not differ from each other significantly by the Tukey's test at 0.05 -probability level.

For electrolyte leakage, there were no significant differences, being on average of $56.5 \%$. In contrast, Godoy (2010) reported that 'Golden' papaya, subjected to different mechanical injuries, had immediate effect on electrolyte leakage, since there was $67 \%$ more leakage of ions compared with control, two days after the injury. For Andrade (2013), cell rupture is the cause of this leakage increase, raising ions within solution and, therefore, contributing to electrical conductivity increase in the cellular medium.

Lower vitamin $\mathrm{C}$ values were observed in uninjured mangoes at stage $5\left(10.38 \mathrm{mg} 100 \mathrm{~g}^{-1}\right)$. Notwithstanding, no significant differences were found when comparing both handling conditions in all stages (Table 2). However, this trait showed a downward trend in both conditions. Values reported here are higher than those described by Cruz et al. (2012), who referred to contents of $3 \mathrm{mg} 100 \mathrm{~g}^{-1}$. However, Lima, Silva and Azevedo (2009) also claimed higher values for 'Tommy Atkins' mango, under conditions of the São Francisco valley (19 mg $\left.100 \mathrm{~g}^{-1}\right)$.

Little variation was observed in $\mathrm{pH}$; all recorded values ranged from 3.6 to 4.2 (Table 2). Interestingly, injuring had no effect on $\mathrm{pH}$. Increasing $\mathrm{pH}$ values are linked to biochemical reactions occurring throughout maturation and in fruit metabolism (ANDRADE, 2013). Similar results were found by Rocha et al. (2001), who observed $\mathrm{pH}$ rise along maturation, varying from 3.23 to 4.51 for stages 1 and 5, respectively.

SS content increased with mango maturity, regardless of injuring. It ranged within $10-14 \%$, from stage 1 to 5 , respectively, corresponding to $28 \% \mathrm{SS}$ gain. Fruit handling had no effect on SS, in all maturation stages (Table 3). Conversely, titratable acidity decreased with fruit maturity, irrespective of impact; however, as in SS, fruit injuring showed no influence on acidity in all stages (Table 3 ). 


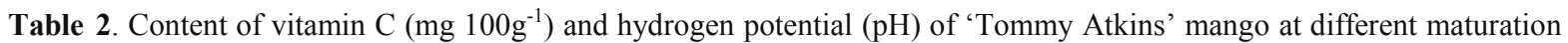
stages, without or with impact injuries, after seven days of storage $\left(28^{\circ} \mathrm{C} \pm 2\right.$ and $\left.66 \% \pm 5 \mathrm{RH}\right)$.

\begin{tabular}{|c|c|c|c|c|}
\hline \multirow{2}{*}{$\begin{array}{l}\text { Maturation } \\
\text { stages }\end{array}$} & \multicolumn{2}{|l|}{ Vitamin C } & \multicolumn{2}{|l|}{$\mathrm{pH}$} \\
\hline & Without impact & With impact & Without impact & With impact \\
\hline 1 & $14.17 \mathrm{ab} \mathrm{A}$ & 15.18 a A & $3.74 \mathrm{~b} \mathrm{~A}$ & $3.63 \mathrm{~b} \mathrm{~A}$ \\
\hline 2 & $13.61 \mathrm{ab} \mathrm{A}$ & 16.18 a A & $3.72 \mathrm{~b} \mathrm{~A}$ & $3.76 \mathrm{~b} \mathrm{~A}$ \\
\hline 3 & 18.86 a A & 16.52 a A & $3.68 \mathrm{~b} \mathrm{~A}$ & $3.72 \mathrm{ab} A$ \\
\hline 4 & $13.61 \mathrm{ab} \mathrm{A}$ & 10.49 a A & $3.94 \mathrm{ab} \mathrm{A}$ & $3.98 \mathrm{ab} \mathrm{A}$ \\
\hline 5 & $10.38 \mathrm{~b} \mathrm{~A}$ & $11.16 \mathrm{a} \mathrm{A}$ & 4.29 a A & $4.21 \mathrm{a} \mathrm{A}$ \\
\hline $\mathrm{CV} \%$ & 12.70 & & 19.46 & \\
\hline Overall mean & 6.41 & 6.93 & 58.34 & 54.64 \\
\hline
\end{tabular}

* Means followed by the same letter, lowercase in column and uppercase in row, do not differ from each other significantly by the Tukey's test at 0.05 -probability level.

Accordingly, SS/TA ratio showed similar behavior, i.e., it tended to increase with fruit maturity, which is mainly attributed to SS increment and TA reduction, favoring SS/TA increased ratios (Table 3). The SS content found in the present study is in agreement with Hojo et al. (2009), who observed an increasing tendency with the advance of maturation, with SS content of $12 \%$ for 'Tommy Atkins' mango. Similar results were reported by Andrade (2013), who worked with postharvest quality of 'Tommy Atkins' mango and observed a decrease in titratable acidity with the advance of maturation. Nonetheless, Sousa, Rocha and Silva (2013) observed a lower content of acidity in fruits subjected to mechanical injury, compared with those without injury, during the storage. Therefore, the decrease in acidity content during storage observed in this study may be explained by the use of organic acids as substrate in respiration (YAMASHITA et al., 2006).

Table 3. Soluble solids (SS, \%), titratable acidity (TA, \% citric acid) and SS/ TA ratio of 'Tommy Atkins' mango at different maturation stages, with (WI) and without (WOI) impact injury, after seven days of storage $\left(28^{\circ} \mathrm{C} \pm 2\right.$ and $66 \% \pm 5$ RH).

\begin{tabular}{llllllc}
\hline Maturation stages & \multicolumn{2}{l}{ Soluble solids (SS) } & \multicolumn{2}{l}{ Titratable acidity (TA) } & SS/TA ratio & \\
\cline { 2 - 7 } & Without impact & With impact & $\begin{array}{l}\text { Without } \\
\text { impact }\end{array}$ & With impact & Without impact & With impact \\
\hline 1 & $10.82 \mathrm{cA}$ & $10.82 \mathrm{bA}$ & $1.26 \mathrm{Aa}$ & $1.40 \mathrm{aA}$ & $8.56 \mathrm{cA}$ & $7.69 \mathrm{cA}$ \\
2 & $11.76 \mathrm{bcA}$ & $12.91 \mathrm{abA}$ & $0.90 \mathrm{bA}$ & $0.87 \mathrm{bcA}$ & $13.25 \mathrm{bcA}$ & $15.66 \mathrm{abcA}$ \\
3 & $12.70 \mathrm{abcA}$ & $13.30 \mathrm{aA}$ & $0.89 \mathrm{bA}$ & $0.92 \mathrm{bA}$ & $14.80 \mathrm{bcA}$ & $14.51 \mathrm{bcA}$ \\
4 & $13.30 \mathrm{abA}$ & $14.21 \mathrm{aA}$ & $0.71 \mathrm{bA}$ & $0.61 \mathrm{cdA}$ & $22.85 \mathrm{bA}$ & $24.13 \mathrm{abA}$ \\
5 & $14.76 \mathrm{aA}$ & $14.61 \mathrm{aA}$ & $0.40 \mathrm{cA}$ & $0.54 \mathrm{dA}$ & $37.21 \mathrm{aA}$ & $27.57 \mathrm{aB}$ \\
\hline CV \% & 8.59 & & 17.00 & & 32.67 & \\
Overall mean & 12.67 & 13.17 & 0.83 & 0.87 & 19.33 & 17.91 \\
\hline
\end{tabular}

* Means followed by the same letter, lowercase in column and uppercase in row, do not differ from each other significantly by the Tukey's test at 0.05 -probability level.

On one hand, the content of reducing sugars had no difference among maturation stages for uninjured fruits (WOI). On the other hand, slight differences among stages were noted in injured fruits (WI), with an increasing trend with maturity. Similarly, the same behavior was registered for nonreducing and total sugars (Table 4). The contents of reducing sugars found here are above those reported by Silva et al. (2012), who referred to $2.94 \%$ in 'Tommy Atkins' mangoes. However, our findings match those by Rocha et al. (2001) and by Morais et al. (2002). In general, maturation promotes sugar increment, mainly owning to hydrolysis of reserve carbohydrates stored during fruit growth on the plant, producing total soluble sugars (TSS) (WILLS et al., 1998).
Significant differences were observed for skin color among maturation stages for both handling conditions, showing great color variation along maturation when fruits were injured (Figure 1). Yet for uninjured fruits, a fruit ripening was observed along maturation, characterized by coloration changes of skin tissue. Likewise, Rocha et al. (2001) reported shifts of skin color, during ripening, from green olive in the first stage, to red in the last one. Besides, Santos et al. (2008) also observed such changes as a function of maturation. Based on our observations, impact injury had no influence on fruit ripening in most of the maturation stages, except for 2 and 3 (Figure 1). 
Table 4. Reducing sugars (\%), non-reducing sugars (\%) and total sugars (\%) of 'Tommy Atkins' mangoes at different maturation stages, with (WI) and without (WOI) impact injury, after seven days of storage $\left(28^{\circ} \mathrm{C} \pm 2\right.$ and $\left.66 \% \pm 5 \mathrm{RH}\right)$.

\begin{tabular}{|c|c|c|c|c|c|c|}
\hline \multirow[t]{2}{*}{ Maturation stages } & \multicolumn{2}{|c|}{ Reducing sugars } & \multicolumn{2}{|c|}{ Non-reducing sugars } & \multicolumn{2}{|c|}{ Total sugars } \\
\hline & $\begin{array}{l}\text { Without } \\
\text { impact }\end{array}$ & With impact & $\begin{array}{l}\text { Without } \\
\text { impact }\end{array}$ & With impact & $\begin{array}{l}\text { Without } \\
\text { impact }\end{array}$ & With impact \\
\hline 1 & 4.92 a A & $4.39 \mathrm{~b} \mathrm{~A}$ & 4.90 a $\mathrm{A}$ & $3.51 \mathrm{~b} \mathrm{~A}$ & 9.83 a $\mathrm{A}$ & $7.90 \mathrm{~b} \mathrm{~A}$ \\
\hline 2 & 4.87 a A & $4.46 \mathrm{~b} \mathrm{~A}$ & $3.82 \mathrm{a} \mathrm{A}$ & $3.72 \mathrm{~b} \mathrm{~A}$ & 8.69 a $\mathrm{A}$ & $8.19 \mathrm{~b} \mathrm{~A}$ \\
\hline 3 & $5.64 \mathrm{a} \mathrm{A}$ & $4.08 \mathrm{~b} \mathrm{~B}$ & $5.01 \mathrm{a} \mathrm{A}$ & $4.01 \mathrm{~b} \mathrm{~A}$ & 10.65 a A & $8.09 \mathrm{~b} \mathrm{~B}$ \\
\hline 4 & 5.26 a B & 6.51 a $\mathrm{A}$ & 4.74 a B & $7.11 \mathrm{a} \mathrm{A}$ & 10.01 a B & $13.62 \mathrm{a} \mathrm{A}$ \\
\hline 5 & $4.93 \mathrm{a} \mathrm{A}$ & $5.73 \mathrm{abA}$ & $5.94 \mathrm{aA}$ & $6.86 \mathrm{aA}$ & $10.88 \mathrm{aA}$ & $12.60 \mathrm{aA}$ \\
\hline $\mathrm{CV} \%$ & 16.72 & & 22.06 & & 14.28 & \\
\hline Overall mean & 5.12 & 5.03 & 4.88 & 5.04 & 10.01 & 10.08 \\
\hline
\end{tabular}

* Means followed by the same letter, lowercase in column and uppercase in row, do not differ from each other significantly by the Tukey's test at 0.05 -probability level.

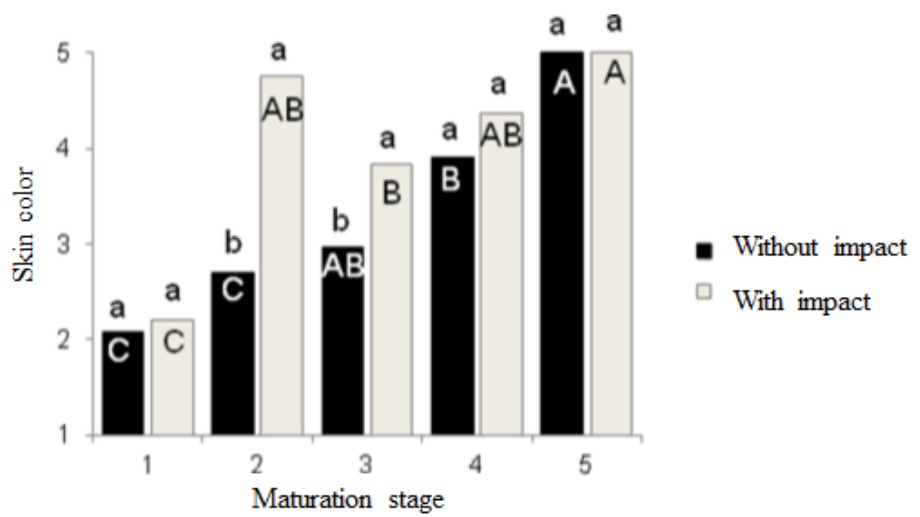

Figure 1. Skin color of 'Tommy Atkins' mangoes at different maturation stages, with (WI) and without (WOI) impact injury, after seven days of storage $\left(28^{\circ} \mathrm{C} \pm 2\right.$ and $\left.66 \% \pm 5 \mathrm{RH}\right)$.

*Means followed by the same letter, uppercase inside the column for the handling conditions (WOI) and (WI) and lowercase outside the column for the maturation stages, do not differ statistically by Tukey test at 0.05 probability level.

Similarly, pulp color changed gradually, increasing as a role of maturity, in both injured and uninjured fruit (Figure 2). In most stages, fruit impact had no effect on pulp coloration (Figure 2). According to Lima, Silva and Azevedo (2009), pulp color alterations are crucial in monitoring of mango growth and maturation, being taken as reference to start 'Tommy Atkins' mango harvest. These responses corroborate the results of Jha, Kingsly and Chopra (2006), who ascertained changes in pulp color, from white to bright yellow, characterizing mango ripeness. Based on these observations, Subedi, Walsh and Owens (2007) recommended this variable as a best maturation index for the mango cultivars 'Kesington Pride', 'Calypso', 'R2E2' and 'Celebration'.

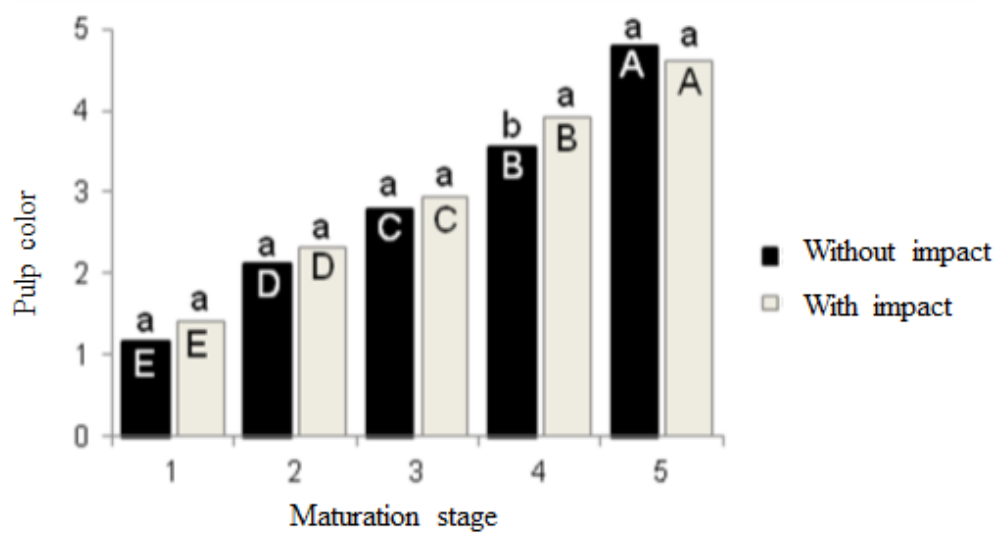

Figure 2. Pulp color of 'Tommy Atkins' mangoes at different maturation stages, with (WI) and without (WOI) impact injury, after seven days of storage $\left(28^{\circ} \mathrm{C} \pm 2\right.$ and $\left.66 \% \pm 5 \mathrm{RH}\right)$.

*Means followed by the same letter, uppercase inside the column for handling conditions, and lowercase outside the column for maturation stages, do not differ from each other statistically by the Tukey's test at 0.05 -probability level. 
The findings regarding the SDI for uninjured fruits showed no differences among maturation stages 1, 2 and 3 (Figure 3), reaching nearly 10\% brightening in the middle of the pulp. At stages 4 and 5 , brightening indices varied from 20 to $30 \%$ and from 40 to $50 \%$, respectively. This behavior arises from conversion of starch into simpler sugars (SANTOS et al., 2008), favoring thus higher SS contents in further maturation stages.

In the same manner for injured fruits, SDI varied along maturation, achieving the highest values at stages 4 and 5, being of about 30 to $40 \%$ brightening. Lower SDIs were seen at stages 1, 2 and 3 , being under $10 \%$ brightening in the middle of the pulp, pointing out a higher content of starch in less mature fruits. This result agrees with Rocha et al. (2001), who reported the larger the area dyed by potassium iodide solution, the higher the starch content. Fruit injuring exhibited no influence on SDI values throughout all stages (Figure 3). Hence, SDI values could not detect potential changes in carbohydrate metabolism because of injuring; therefore, making this index unsuitable for detection of fruit impact injury in mangoes.

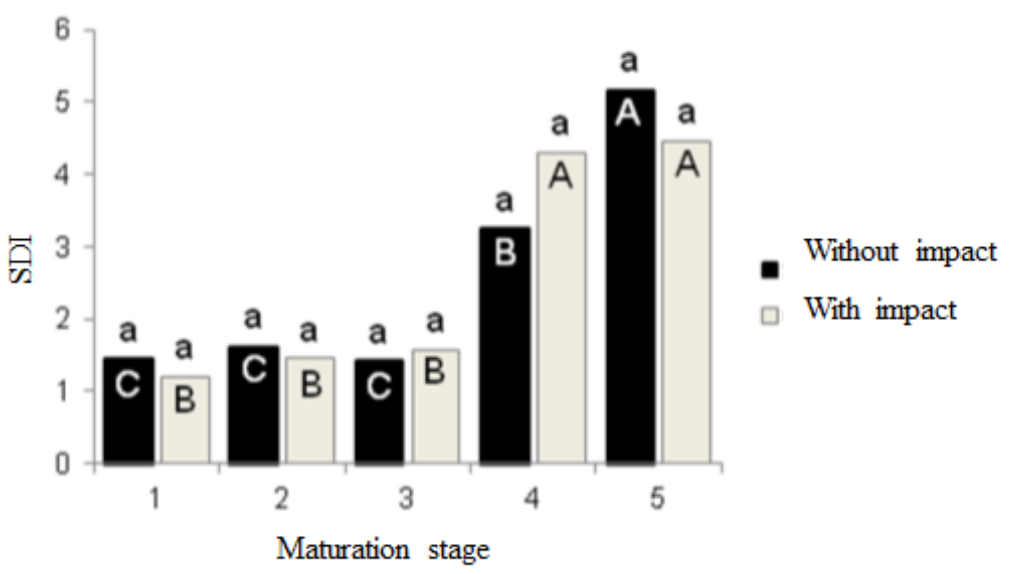

Figure 3. Starch degradation index (SDI) of 'Tommy Atkins' mangoes at different maturation stages, with (WI) and without (WOI) impact injury, after seven days of storage $\left(28^{\circ} \mathrm{C} \pm 2\right.$ and $\left.66 \% \pm 5 \mathrm{RH}\right)$.

*Means followed by the same letter, uppercase inside the column for handling conditions, and lowercase outside the column for maturation stages, do not differ from each other statistically by the Tukey's test at 0.05 -probability level.

Uninjured fruits showed a good and positive correlation between SDI with skin/ pulp color, $\mathrm{pH}$, soluble solids, non-reducing sugars and SS/TA ratio. Although FML, TA and vitamin $\mathrm{C}$ had a good correlation among them, it was negative, which suggests the higher the SDI, the lower these variables could be (Table 5). For injured fruits, correlations among pulp color, vitamin $\mathrm{C}$, reducing sugars, non-reducing sugars and total sugars were higher compared to mangoes without impact (Table 5). This behavior highlights a well representation of carbohydrate transformations by
SDI variations along fruit maturation, mainly for pulp color changes and the area spotted with iodinepotassium iodide solution, evaluated from this index. The strong correlation of SDI with skin and pulp colors allow us to infer that the greener the skin and the whiter the pulp, the less mature the fruit and the larger the dyed area in the pulp are. For further maturation stages, the redder the skin and the more orange the pulp, the smaller the dyed area, corroborating Rocha et al. (2001), who reported similar results.

Table 5. Coefficients of correlation (r) for fresh mass loss (FML), skin color, pulp color, electrolyte leakage (EL), vitamin $\mathrm{C}, \mathrm{pH}$, titratable acidity, soluble solids (SS), SS/TA ratio, reducing sugars, non-reducing sugars and total sugars, correlated with starch degradation index (SDI) of 'Tommy Atkins' mangoes.

\begin{tabular}{llc}
\hline & Correlation (r) with SDI & \\
\cline { 2 - 3 } Trait & Without impact & With impact \\
\hline Fresh mass loss & -0.67 & -0.25 \\
Skin color & 0.96 & 0.59 \\
Pulp color & 0.90 & 0.92 \\
Electrolyte leakage & 0.29 & 0.24 \\
Vitamin C & -0.76 & -0.96 \\
pH & 0.99 & 0.93 \\
Titratable acidity & -0.88 & -0.83 \\
Soluble solids & 0.89 & 0.73 \\
\hline
\end{tabular}


Table 5. Continuation.

\begin{tabular}{lcc}
\hline & Correlation $(\mathrm{r})$ with SDI \\
\cline { 2 - 3 } Trait & Without impact & With impact \\
\hline SS/TA ratio & 0.98 & 0.94 \\
Reducing sugars & -0.25 & 0.93 \\
Non-reducing sugars & 0.70 & 0.99 \\
Total sugars & 0.53 & 0.98 \\
\hline
\end{tabular}

\section{CONCLUSIONS}

Impact injury had no influence on fruit quality in any of the studied maturation stages;

Starch degradation index is unsuitable in indicating fruits with impact injuries;

Starch degradation index is well correlated with pulp color, vitamin $\mathrm{C}, \mathrm{pH}$, titratable acidity, soluble solids, SS/TA ratio and non-reducing sugars.

\section{REFERENCES}

ASSOCIATION OF OFFICIAL ANALYTICAL CHEMISTS - AOAC. Official Method of Analysis. 18 ed. Washington, DC, USA, 2005.

ANDRADE, M. E. L. Qualidade pós-colheita de manga Tommy Atkinse tratada com água eletrolisada. 2013. 66 f. Tese (Doutorado em Fitotecnia. Área de concentração: Agricultura Tropical) - Universidade Federal Rural do Semi-Árido, Mossoró, 2013.

BROOKFIELD, P. et al. Starch degradation and starch pattern indices: interpretation and relationship to maturity. Postharvest Biology and Technology, Amsterdam, v. 11, n. 1, p. 23-30, 1997.

CRUZ, J. A.; HELBIG, E. Teor e estabilidade da vitamina $\mathrm{C}$ em sucos de frutas in natura refrigerados. In: XXI CONGRESSO DE INICIAÇÃO CIENTÍfICA, 21, 2012, Pelotas. Anais... Pelotas: UFPEL, 2012. CR-ROM.

DURIGAN, M. F. B.; MATTIUZ, B. H.; DURIGAN, J. F. Injúrias mecânicas na qualidade pós-colheita de lima ácida 'Tahiti' armazenada sob condição ambiente. Revista Brasileira de Fruticultura, Jaboticabal, v. 27, n. 3, p. 369-372, 2005.

FAN, X. et al. Changes in amylose and total starch content in 'Fuji' apples during maturation. HortScience, Alexandria, v. 30, n. 1, p. 104-105, 1995.

FERREIRA, D. F. Sisvar: um sistema computacional de análise estatística. Ciência e Agrotecnologia, Lavras, v. 35, n. 6, p. 1039-1042, 2011.
GODOY, A. E. et al. Injúrias mecânicas e seus efeitos na qualidade de mamões 'Golden'. Revista Brasileira de Fruticultura, Jaboticabal, v. 32, n. 3, p. 682-691, 2010.

HOJO, R. H. et al. Qualidade de manga 'Tommy Atkins' pós-colheita com uso de cloreto de cálcio na pré-colheita. Revista Brasileira de Fruticultura, Jaboticabal, v. 31, n. 1, p. 62-70, 2009.

INSTITUTO ADOLFO LUTZ. Normas Analíticas do Instituto Adolfo Lutz. 4. ed. São Paulo, SP: IAL, 2008. p. 126-128.

JHA, S. N.; KINGSLY, A. R. P.; CHOPRA, S Physical and mechanical properties of mango during growth and storage for determination of maturity. Journal of Food Engineering, Davis, v. 72, n. 1, p. 73-76, 2006.

LIMA, M. A. C.; SILVA, A. L.; AZEVEDO, S. S. N. Evolução de indicadores do ponto de colheita em manga 'Tommy Atkins' durante o crescimento e a maturação, nas condições do vale do São Francisco, Brasil. Ciência Agrotecnologia, Lavras, v. 33, n. 2, p. 432-439, 2009.

MANICA, I. et al. Manga: Tecnologia, produção, agroindústria e exportação. 1. ed. Porto Alegre, RS: Cinco Continentes, 2001. 617p.

MORAIS, P. L. D. et al. Ponto de colheita ideal de mangas Tommy Atkins destinadas ao mercado Europeu. Revista Brasileira de Fruticultura, Jaboticabal, v. 24, n. 3, p. 671-675, 2002.

PACHECO, A. L. A. Anuário Brasileiro de Fruticultura. Piracicaba: CEPEA, 2015. p. 58.

PROTRADE. Mango - Manual de exportacion: frutas tropicales y hortalizas. Eschborn: GTZ, 1992. $34 \mathrm{p}$.

ROCHA, R. H. C. et al. Uso do índice de degradação de amido na determinação da maturidade da manga 'Tommy Atkins'. Revista Brasileira de Fruticultura, Jaboticabal, v. 23, n. 2, p. 302-305, 2001.

SANTOS, D. B. et al. Caracterização físico química dos estádios de maturação da manga "Tommy 
Atkins" produzida no município de Iaçú-BA. Magistra, Cruz das Almas, v. 20, n. 4, p. 342-348, 2008.

SEREK, M. et al. Inibition of ethylene-induced cellular senescence symptoms by 1-methylcyclopropene, a new inhibitor of ethylene action. Physiologia Plantarum, Hannover, v. 94, n. 2, p. 229-232,1995.

SILVA, A. C. et al. Caracterização e correlação física e química dos frutos de cultivares de mangueira em São Manuel, São Paulo. Magistra, Cruz das Almas, v. 24, n. 1, p. 15-26, 2012.

SOUSA, F. A.; ROCHA, R. H. C.; SILVA, H. S. Manga 'Tommy Atkins' submetida a injúrias mecânicas pós-colheita. Revista Verde, Mossoró, v. 8, n. 5 , p. $14-21,2013$.

STROHECKER, R; HENINING, H. M. Análisis de vitaminas: métodos comprobrados. Madrid: Paz Montalvo, 1967, 42 p.

SUBEDI, P. P.; WALSH, K. B.; OWENS, G. Prediction of mango eating quality at harvest using short-wave near infrared spectrometry. Postharvest Biology and Technology, Amsterdam, v. 43, n. 3, p. 326-334, 2007.

WILLS, R. et al. Postharvest: an introduction to the physiology \& handling of fruit, vegetables \& ornamentals. 4th ed. Wallingford: New South Wales University Press, 1998. 262 p.

YAMASHITA, F. et al. Morangos embalados com filme de Ppolicloreto de vinila (PVC). Semina: Ciências Agrárias, Londrina, v. 27, n. 3, p. 429-436, 2006. 